\title{
Norming the Norm of Relationality: A Theological and Interreligious Exploration of the Trinitarian Doctrine
}

\author{
David Muthukumar S.1)* \\ 1)Ph.D. Candidate, Fuller Theological Seminary, Pasadena, CA \\ ${ }^{*}$ Correspondent author: david.muthukumar@gmail.com
}

Received: 05 December 2019/Revised: 18 February 2020/Accepted: 11 March 2020

\begin{abstract}
Should all metaphysical reflections on the Trinity begin with the "substance/essence" ontology? However, this approach has more often led to regressive metaphysical speculations, as is often witnessed in the historical theology of the Church. Are there alternative models that we can glean from the history of the Church that can provide a new means of conceptualizing the doctrine of the Trinity? This essay considers this issue at length to suggest a "relational ontology" paradigm in constructing the Trinitarian doctrine. It also makes use of Vishishtadvaita (Qualified Non-Dualism in Hindu philosophy) conception of "body-soul" analogy to render a "qualitative panentheistic" model in construing the doctrine of the Trinity. These theological and interreligious explorations are expected to shed more light on the issue.
\end{abstract}

Keywords: doctrine, Trinity, theology, ontology, Viśiștādvaita

\begin{abstract}
Abstrak
Haruskah semua refleksi metafisik tentang Trinitas bermula dengan ontologi "substansi/esensi"? Pendekatan ini seringkali menyebabkan kemunduran spekulasi metafisik, sebagaimana disaksikan dalam teologi sejarah gereja. Apakah ada model alternatif yang bisa kita ambil dari sejarah gereja yang dapat menyediakan cara baru untuk mengkonsepkan doktrin Trinitas? Esai ini mempertimbangkan isu ini panjang lebar untuk menunjukkan paradigma "ontologi relasional" dalam membina doktrin Trinitarian. Hal ini juga membuat penggunaan Vishishtadvaita (Kualifikasi Non-Dualisme dalam filsafat Hindu) konsepsi analogi "tubuh-jiwa" untuk membuat model "kualitatif panenteistik" dalam membangun doktrin Trinitas. Eksplorasi teologi dan keberagaman agama ini diharapkan lebih menjelaskan masalah ini.
\end{abstract}

Kata-kata Kunci: Doktrin, Trinitas, teologi, ontologi, Viśisțāadvaita

\section{Introduction}

While the Church Councils of the Early Christian Church were grappling with the issues of understanding the divinity of Jesus Christ (homoousion with Father). His human-divine natures (the hypostatic 
union), and the relation of the Holy Spirit with the Father and the Son (the filioque clause or not), a trinitarian conception of the Godhead gradually evolved and provided an underlying framework for further reflections. ${ }^{1}$ It can be perceived from the sequence of creedal affirmations, primarily the Nicene-Constantinople (381) and the Chalcedonian (45l) creeds. This seems to indicate that such a trinitarian conception was not innate to the primal Church's faith matrix. It was a progressive understanding that crystalized only toward the third century C.E. and the Trinity (Latin Trinitas) itself is represented by an extra-biblical word (attributed to Tertullian of $3^{\text {rd }}$ Century, C.E.) which is a derivative from the biblical accounts that signify a 'plurality' in the Godhead? The 'majestic' plural אלוהים (Elohim), the 'Angel of the Lord' in the Old Testament (Gen. 16:10, 18:1, Josh. 5:13-15), the Baptismal formula in Matthew 28:19, worship being offered to Jesus Christ in the New Testament along with God the Father (Phil. 2:10), and the operations of the Holy Spirit, both as the Spirit of God as well as the Spirit of Jesus (Matt. 3:16, Phil. 1:19). Thus, in the history of the Church, the doctrine of the Trinity has emerged out of her ardent believers' grasp of the Scriptural reality of the Divine. And, it began to be the core of all her faith affirmations. Karl Barth captures this emphasis, "With the confession of God's Triunity stands or falls the whole of Christianity, the whole of special revelation. This is the kernel of the Christian faith, the root of all dogmas, the substance of the new covenant." ${ }^{2}$ the Trinity doctrine did not enjoy the central place in Christian articulations for long. While the form of trinitarian affirmation is maintained through creed and liturgy for practical purposes. The church began to ignore the centrality of the doctrine of the Trinity. As Colin Gunton points out,

[There is a] manifest inadequacy of the theology of the church ... that it has never seriously and consistently been rooted in a conception of the being of God as triune.... There is a widespread assumption that the doctrine of the Trinity is one of the difficulties of Christian belief: a kind of intellectual hurdle to be leaped before orthodoxy can be acknowledged. ${ }^{3}$

Karl Rahner also laments, “... despite their orthodox confession of the Trinity, Christians are, in their practical life, almost mere

\footnotetext{
${ }^{1}$ Probably is began as a binitarian conception (see Larry W. Hurtado, One God, One Lord: Early Christian Devotion and Ancient Jewish Monotheism (Philadelphia: Fortress Press, 2005), $3 \mathrm{ff}$.

2 Karl Barth, Church Dogmatics I/1 $\$ \$ 8-12$ : The Doctrine of The Word of God (T\&T Clark, 2010), 303.

${ }^{3}$ Colin E. Gunton, The Promise of Trinitarian Theology (Edinburgh: T\&T Clark, 2003), 56.
} 
monotheists." We must be willing to admit that, should the doctrine of the Trinity have to be dropped as false, the major part of religious literature could well remain unchanged. ${ }^{4}$ According to Rahner, the doctrine of the Trinity is not even adequately tangential to the Christian faith, let alone being its core. He goes back in history and squarely places the blame for this tendency to shun the doctrine of the Trinity on Augustinian-Western theology and Thomas Aquinas. Diverging from Peter Lombard's Sentences, following Augustine, Aquinas prioritized the treatise 'On the One God' (De Deo Uno) over against 'On the Triune God,' (De Deo Trino) thus elevating the discourses on the essence of God against the trinitarian God. ${ }^{5}$ This, according to Rahner, has preserved the 'monotheistic' preference by emphasizing the principle of One God and has relegated the trinitarian conception to mere adiaphora. However, thanks to the clarion call given by Barth that 'with the confession of God's Triunity stands or falls the whole of Christianity,' in the past few decades, the doctrine of the Trinity has regained a renewed interest in the theological (if not doxological) sphere. It is indeed a welcome break for the theological academia to strive to reflect on this central tenet of Christian faith.

Let us now turn our attention on Rahner's earlier quote, where he calls Christians 'practically mere monotheists,' citing their neglect of the trinitarian emphasis. This raises several interesting issues. We need to ask: Are Christians not monotheists because they confess the Trinity? What is the relationship between 'Monotheism' and 'the Trinity'? What is the relationship between the economic Trinity as God-Self-Revealed and the immanent Trinity as God-in-Self? Can we say something about God in God's inner relations as we make observations from Scriptural (historical) Revelation? The major caveat is that if one attempts to address these metaphysical concerns from the 'classical' standpoint by prioritizing a 'substance ontology', it is most likely that we will be caught up in a vortex of endless regression. ${ }^{6}$ What is proposed in this article is that if we can start through the less traveled 'relational ontology' route, there is a greater potential to sufficiently address the aforementioned concerns. For this purpose, I intend to evaluate the limits and possibilities of certain concepts that are considered as vital for our understanding of the doctrine of the Trinity: a) monotheism-Trinity relations; b) use of 'relational ontology' replacing 'substance ontology'; c) oikonomia-theologia relations; For this purpose, the Viśiștādvaita (qualified

\footnotetext{
${ }^{4}$ Karl Rahner and J. F. Donceel, The Trinity (London: New York: Burns \& Oates, 2001), 9, http://public.eblib.com/choice/publicfullrecord. aspx? $\mathrm{p}=436043$.

${ }^{5}$ Karl Rahner and J. F. Donceel, The Trinity, 10.

${ }^{6}$ This is evident in the 'West-East' debates that pit Augustine and his successors against the Cappadocians and other Eastern Patriarchs.
} 
non-dualism) as an interreligious insight will be utilized to understand the oikonomia-theologia relations. Finally, an evaluation of the limits and possibilities of reading back from oikomomia to theologia will be attempted in order to construct 'theologically proper' statements about the Trinity. ${ }^{7}$

\section{Method}

Qualitative research with a Trinitarian hermeneutic approach. ${ }^{8}$ This essay considers this issue at length to suggest a "relational ontology" paradigm in constructing the Trinitarian doctrine. It also makes use of Vishishtadvaita (Qualified Non-Dualism in Hindu philosophy) conception of "body-soul" analogy to render a "qualitative panentheistic" model in construing the doctrine of the Trinity.

\section{Discussion}

\section{Whose Monotheism? Which Trinity ${ }^{9}$}

To begin with, in order to understand the concept of the Trinity, there is a need to explore its relation to 'monotheism.' When we use terms like 'One ousia, three hypostases,' or Triune Being to define the Trinity, can we still claim to be monotheists? And, what are the parameters we need to use to evaluate monotheism? Brian Leftow says, "The Christian version of monotheism should complete, perfect, or fulfill its Jewish version. It should be a monotheism a Jew could accept as monotheistic and completion of Jewish monotheism."10 So, to consider the Monotheism-Trinity relations, Leftow says, we need to subject the Christian monotheism to the procrustean bed of Jewish monotheism. Daniel Howard-Snyder includes Islamic monotheism along with Jewish monotheism as the qualifying criteria for Christian monotheism. ${ }^{11}$ One

7 'Theologically proper' refers to the coherent statements about the Trinitarian God, that acknowledges its limitations within the possibilities.

${ }^{8}$ C. Kavin Rowe, "Biblical Pressure and Trinitarian Hermeneutics," Pro Ecclesia: A Journal of Catholic and Evangelical Theology 11, no. 3 (2002): 295-312, https://doi.org/10.1177/106385120201100303; Christine Helmer, "Luther's Trinitarian Hermeneutic and the Old Testament," Modern Theology 18, no. 1 (2002): 49-73, https://doi.org/10.11l1/1468-0025.00176.

${ }^{9}$ Borrowed from Thomas McCall, Which Trinity? Whose Monotheism? Philosophical and Systematic Theologians on the Metaphysics of Trinitarian Theology (Grand Rapids, Mich.: W.B. Eerdmans, 2010).

${ }^{10}$ William Hasker, Metaphysics and the Tri-Personal God (Oxford, United Kingdom: Oxford University Press, 2013). Citing 'Anti Social Trinitarianism,' in McCall and Rea, Philosophical and Theological Essays, 72.

${ }^{11}$ Ibid., citing Daniel Howard-Snyder, 'Trinity Monotheism,' Philosophia Christi, 5/2 (2003), 402. 
can agree with William Haskar that both Leftow and Howard-Snyder are wrong for imposing such external evaluation criteria; both Jewish and Islamic conception of monotheism are defined by their stark opposition to the Christian doctrines of the Trinity and incarnation. ${ }^{12}$ It will not do justice to the Christian faith claims if we evaluate Christian monotheism (defined by the Trinitarian belief) by using such external parameters. However, as McCall notes, the better place to start would be to consider 'the monotheism of the Second Temple Judaism as it was received and drawn upon by John, Paul, and the other authors of the New Testament. ${ }^{13}$ First Century Judaism - the temple, culture, and social settings--forms the backdrop for early Christianity. Jesus and his twelve disciples, as well as most of the early believers, including Paul, were Jews. Moreover, the monotheistic belief was one of the distinguishing factors of the Jewish belief, and any compromise on that principle was severely condemned. Confessing and worshipping Yahweh, the God who has chosen Israel to be His people as the one and only God was the primary faith tenet. Given this strict monotheistic background of that time, the early Christian believers from Judaism seem to have assimilated the ascription of worship to Jesus well early in the life of the Church. Since this is the case, we need to explore the question: 'How did the Jewish disciples of Jesus reconcile their monotheistic adherence while ascribing worship to the 'human' Jesus'?

Larry W. Hurtado observes, 'the religious mentality of the first Christians was undeniably shaped especially by the Jewish tradition ... that provided the initial conceptual categories by which to interpret the religious experiences that provoked the earliest Christian convictions. ${ }^{14}$ After examining the 'Divine Agency,' 'Personification' of divine attributes (Wisdom, Logos), 'Exalted Patriarchs', and 'Angelology' of Jewish tradition, Hurtado concludes, "the earliest Christian devotion constituted a significant mutation or innovation in Jewish Monotheistic tradition ... but at an early stage, it exhibited an immediate and significant difference in character from Jewish devotion." ${ }^{15}$ Christian piety toward Jesus rose out of existing Jewish traditions but was conceived in radically different terms, especially in terms of Jesus' relation to the One God. New Testament uses different titles for Jesus. He was called 'the Christ,' the Jewish Messiah, 'the Son of God,' and o кupıs (ho Kurios), 'the Lord.' While кopros in Greek could be just a deferential term of address like 'Sir' or 'Master,' in the New Testament, it was often used as the translation for the Tetragrammaton הוהי (YHWH),

\footnotetext{
${ }^{12}$ Ibid., 178.

${ }^{13}$ Thomas H McCall, Which Trinity? Whose Monotheism? 57.

${ }^{14}$ Hurtado, One God, One Lord, 94.

${ }^{15}$ Ibid., 99.
} 
the most sacred Name for the Jews that was seldom pronounced. Paul uses kvpros to designate the LORD as a Greek substitute for God's name. Hurtado points out that it is quite noteworthy that citing the Old Testament passages, which are primarily referring to God, Paul applies the same passages to Jesus, making him the LORD. He finds Romans 10: 13 (Joel 2:32), 1 Corinthians 1:31 (Jer. 9:23-24) l Corinthians 10:26 (Ps. 24:1), 2 Corinthians 10:17 (1 Cor. 8:6; Jer. 9:23-24) as illuminating. ${ }^{16}$

William Haskar finds 1 Corinthians 8:5-6 as unique, arguing that Paul is affirming a two-fold confession of 'one God the Father' and one Lord Jesus Christ. ${ }^{17}$ He concludes that Paul, in making this strong association of Jesus with God, is restating the traditional Jewish confession and worship of God's exclusivity as proclaimed in the עמש (Shema) found in Deuteronomy 6:4, "Hear, O Israel: The Lord our God is one Lord." 18 Again in Philippians 2:10, Paul states, "so that at the name of Jesus every knee should bend, in heaven and on earth and under the earth, and every tongue should confess that Jesus Christ is Lord to the glory of God the Father." ${ }^{19}$ Haskar observes that this presentation of Jesus' exaltation is in cross-reference to Isaiah 45:23, where God avers, "To me, every knee shall bow, every tongue shall swear." 20 He notes, "The universal acknowledgment and obeisance that in Isaiah is directed to God are now to be given to Jesus'. ${ }^{21}$ Richard Bauckham amplifies this,

The concern of early Christology was not to fit Jesus to some pre-existing model of an intermediary figure subordinate to God. The concern of early Christology, from its root in the exegesis of Psalm 110:1 and related texts, was to understand the identification of Jesus with God. Early Jewish monotheism provided a little precedent for such a step, but it was so defined and so structured as to be open for such a development. ${ }^{22}$

Further, in the passage in Philippians 2:6-1l, which is widely recognized as being possibly from an early Christian hymn, Paul is not constrained to give any explanations or justifications for the radically

\footnotetext{
${ }^{16}$ Hurtado, One God, One Lord, 112.

${ }^{17}$ Hasker, Metaphysics and the Tri-Personal God, 181; Gordon D. Fee, Jesus the Lord According to Paul the Apostle: A Concise Introduction (Grand Rapids: Baker Academic, 2018); Made Astika, "Doctrine of Trinity: A Theological Approach of Evidence of The Trinity in The New Testament," Jurnal Jaffray 10, no. 2 (October 1, 2012): 1-15, https://doi.org/10.25278/jj7l.vl0i2.50.

${ }^{18}$ Hasker, Metaphysics and the Tri-Personal God, 181.

${ }^{19}$ NRSV.

${ }^{20}$ Hasker, Metaphysics and the Tri-Personal God, 182.

${ }^{21}$ Ibid., 182.

22 Richard Bauckham 'The Throne of God and the Worship of Jesus,' in Newman et al., Jewish Roots of Christological Monotheism, SJSJ, (Leiden: E J Brill, 1999) pp. 43-69, 64.
} 
stated Christological affirmations and the application of the Isaiah passage to Christ. ${ }^{23}$ Not only are these affirmations and their implications are taken for granted, but it is also well assumed that these will be freely understood and accepted by his readers. ${ }^{24}$ Haskar labels this 'Christological monotheism,' whereby the pattern of beliefs about God and about Jesus converge and a 'reconstituted' monotheism, in which Jesus is honored and reverenced along with God. ${ }^{25}$ Hurtado sums it up, saying, 'when this constellation of devotional actions is set in the general first-century religious context, it is correctly understood as constituting the cultic worship of Jesus. ${ }^{26}$ Thus, the earliest Christians who were primarily from a Jewish background assimilated the worship of Jesus along with YHWH, by 'reconstituting' their understanding of monotheism.

Perhaps initially, the Spirit was understood as the power of God that made possible the faith in Christ, but in Romans 8:26-7; Ephesians 4:30 and in John 14:26, personal terms are used to depict the 'person and activity' of the Spirit. ${ }^{27}$ Thus, it is no exaggeration to say that the intersection of Christology and Pneumatology resulted in the redefinition of the Second Temple monotheism. ${ }^{28}$ If we ignore this historical data, the possibility of understanding the Trinity and its defining concepts will be a rudderless journey.

Hence, the relationship between Christian monotheism and the Trinity should be construed as an intersection of Christology and Pneumatology with Second Temple Monotheism. This 'historical recognition' (in oikonomia) of the early Christian understanding of God's Self-Revelation sets the proper parameters for Christian monotheism. Also, in this historical recognition, we can have a glimpse of the interlocking pattern of the relations of the Father, the Son, and the Holy Spirit as One God. This leads us to an acknowledgment that God's SelfCommunication to humanity within the history of salvation has unveiled a 'relationship paradigm' within the Trinity. Furthermore, it is only fit to commence any humble theologizing from this 'relational' starting point.

\section{Norming Relations}

This 'relational' starting point, in terms of theologizing, does signal a break with the previous tradition of 'substance metaphysics.' Greek

\footnotetext{
${ }^{23}$ Hasker, Metaphysics and the Tri-Personal God, 182.

${ }^{24}$ Hasker, Metaphysics and the Tri-Personal God, 182.

${ }^{25}$ Ibid.

${ }^{26}$ Hasker, Metaphysics and the Tri-Personal God, 182. citing Larry Hurtado, Lord Jesus Christ: Devotion to Jesus in Earliest Christianity (Grand Rapids, MI: Eerdmans, 2003), 32.

${ }^{27}$ Hasker, Metaphysics and the Tri-Personal God, 184.

${ }^{28}$ Ibid.
} 
philosophy, particularly the Aristotelian metaphysics, employed the binary of substance and accidents, where the 'oneness, sameness' (immutable essence) were given precedence over the diversity, alterity, and relationality (accidents). ${ }^{29}$ By this, it would mean that the unity of God - the 'ontology' of God - consists mainly in the 'substance' of God, and God first is God, and then only God exists as Trinitarian persons. ${ }^{30}$ As Catherine Mowry LaCugna observes, if the divine substance is made the highest ontological principle - the substratum of divine and the ultimate source of all that exists - then God and everything else is, finally, impersonal. ${ }^{31}$ By focusing only on the 'inner' life of God--on the intra-relations of Father, Son, and Spirit--instead of God's relation to the world, eventually the doctrine of the Trinity could speak only of a Trinity locked up in itself, related to itself, contemplating itself perfectly and eternally, but essentially unrelated to us. ${ }^{32}$

But John Zizioulas notes, in the thoughts of the Greek Fathers such Aristotelian binary between primary and secondary substance was utterly absent. ${ }^{33}$ He argues that the Cappadocian Fathers started a metaphysical revolution of the doctrine of the Trinity by elevating hypostasis as the highest principle in the place of ousia, and 'person' instead of 'substance.'34 This identification of 'hypostasis' with 'person' signifies that the 'person' is not an appendage to a being, but it is 'itself the hypostasis of the being,' and also being is not an absolute category in itself, but it is the person that constitutes the being. ${ }^{35}$ While the 'substance ontology' signifies that the ontological 'principle' of God is to be found in the substance, that is, in the very 'being' of God and not in the 'person,' in the patristic theology of the Trinity, the unity of God--the being and life of God--does not consist in the one substance of God but in the hypostasis. ${ }^{36}$ Robert W. Jenson also agrees that the Cappadocians arrived at a conceptual category, by ordering Origen's hypostases and their idea of homoousia, 'making the hypostases' mutual relations structures of the

${ }^{29}$ Veli-Matti Kärkkäinen, Trinity and Revelation (Grand Rapids, Michigan:

William B. Eerdmans Publishing Company, 2014), 246.

30 Jean Zizioulas, Being as Communion: Studies in Personhood and the Church

(Crestwood, N.Y.: St. Vladimir's Seminary Press, 1993), 38.

${ }^{31}$ Catherine Mowry LaCugna, God for Us: The Trinity and Christian Life (San

Francisco: HarperSanFrancisco, 2006), 101.

${ }^{32}$ LaCugna, God for Us: The Trinity and Christian Life, 101.

33 Zizioulas, Being as Communion, 38.

${ }^{34} \mathrm{Ibid}, 39$. In other words, from an adjunct to a being (a kind of mask), the person becomes the being itself and is simultaneous--the constitutive element (the 'principle' or 'cause') of beings.

35 Ibid.

36 Zizioulas, Being as Communion, 38. 
one God's life rather than risers of the steps from God down to us. ${ }^{37}$ This 'communion theology' redefined the idea of 'relation or person'

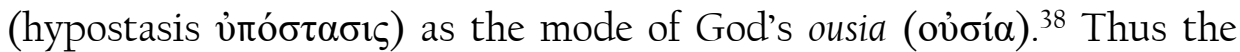
persons conceived as relations that subsist in God, as the possessor of Godhead, provided an answer to the 'substance' problem..$^{39}$

LaCugna further elaborates this: "Relation as a category, unlike 'substance' speculations, just refers to one thing that is in relation to another and does not indicate what something is in itself." 40 She also notes that when we talk in terms of relation, we are not talking about what God's ousia is, and hence, it does not violate the principle that God's ousia is not knowable. ${ }^{41}$ In other words, the attributes are recast in relational categories as God in relation to the world. This takes serious note of the fact that God is essentially infinite, and any talk about God is circumscribed by finite human conceptions and linguistic expressions. The shift from 'substance' to 'relational' categories avoids the risk of speculations on God's 'essence,' and provides sufficient scope to talk about God both in the salvation history sphere and also to make coherent statements about God's inner relations. ${ }^{42}$ F. LeRon Shults observes "Relationality helps conceive of the nature and activity of God in a dynamic way, going back to the testimonies in Scripture."43

LaCugna also avers such a relational Trinitarian theology is primarily a theology of relationship that explores the mysteries of love, relationship, personhood, and communion within the framework of God's Self-Revelation in the person of Christ and the activity of the Holy Spirit. ${ }^{44}$ This relational conception of God is in sync with the early Christian believers' historical recognition of the 'relational paradigm' in the Triune God's Self-Revelation, which enabled them to reconstitute the Jewish Monotheism by the intersection of Christology and Pneumatology. This relational understanding also specifies how we can understand God--by observing the realm of God's salvific sphere, the world. Thus, the early Christians were able to conceive God in Triunity, however radical and outrageous it sounded to the others. Therefore, we

\footnotetext{
${ }^{37}$ Robert W. Jenson, The Triune Identity: God, according to the Gospel (Philadelphia: Fortress Press, 2002), 106.

${ }^{38}$ LaCugna, God for Us, 243.

${ }^{39}$ Ibid.

${ }^{40}$ LaCugna, God for Us, 97.

${ }^{41}$ Ibid., 96.

42 Jenson, The Triune Identity. 107. 'Instead of discussing the attributes of God as the essence of God ('divine simplicity'), a dynamic epistemology is proposed here, in which the essence of God itself is conceived relationally.'

${ }^{43}$ F. LeRon Shults, Reforming the Doctrine of God (Grand Rapids, Mich.: W.B. Eerdmans Pub. Co., 2005), 10.

${ }^{44}$ LaCugna, God for Us, 1.
} 
can infer that our study of God's being will also enable us to make statements about the being of God--however inadequate it may be. This, then, leads us to ponder the relationship between oikonomia (salvation history of God) and theologia (God-in-Self).

\section{Oikonomia - Theologia}

Karl Rahner is categorical when he says that to understand and explicate the doctrine of the Trinity, the right place to look at is the 'salvation history.' He says, we should "confidently look for access into the doctrine of the Trinity in Jesus and in his Spirit, as we experience them through faith in salvation history." ${ }^{45}$ Rahner proceeds to formulate his Grundaxiom: "The economic Trinity is the immanent Trinity, and the immanent Trinity is the economic Trinity." Before we advance to evaluate the two clauses of his axiom, let us briefly look at the terms 'economic Trinity' and 'immanent Trinity.'

LaCugna notes that the terms 'economic Trinity' and 'immanent Trinity' (used interchangeably with oikonomia and theologia) are 'ways of speaking about the life and work of God ${ }^{46}$ The phrase 'economic Trinity' signifies the manifestations of God's activity in the world, associated with the names of Father, Son, and Spirit - in terms of the missions and now these missions (Redemption and Sanctification) bring about communion between God and humankind. ${ }^{47}$ Whereas, the 'immanent Trinity' refers to "the reciprocal relationships of Father, Son, and Spirit to each other," which is considered apart from God's mission in the world. ${ }^{48}$ In Rahner's theology, the economic Trinity is the historical manifestation of that 'eternal self-communication' (the immanent Trinity) in the missions of Jesus Christ and the Spirit. ${ }^{49}$ By identifying the economic Trinity with immanent Trinity, Rahner states, "What God has revealed and given in Christ and the Spirit is the reality of God as God is from all eternity." 50

Through the historicizing of God's Self-Communication in the 'missions,' Rahner claims:

But if it is true that we can really grasp the content of the doctrine of the Trinity only by going back to the history of salvation and of grace, to our

${ }^{45}$ Rahner and Donceel, The Trinity, 152.

${ }^{46}$ LaCugna, God for Us, 211.

47 Ibid.

48 Ibid., 212.

${ }^{49}$ David Lincicum, 'Economy and Immanence: Karl Rahner's Doctrine of the Trinity,' European Journal of Theology 14, no. 2 (2005): 113,

http://biblicalstudies.org.uk/pdf/ejt/14-2_lll.pdf.

$50 \mathrm{Ibid}$. (italics original). 
experience of Jesus and of the Spirit of God, who operates in us, because in them we really already possess the Trinity itself as such, then there never should be a treatise on the Trinity in which the doctrine of the 'missions' is at best only appended as a relatively unimportant and additional scholion. ${ }^{51}$

According to Rahner, the doctrine of 'missions' is the doctrine of 'immanence' (divine Self-Life). ${ }^{52}$ Though he does not deny the 'free decree of God to communicate himself (supernaturally), he avers that the force of such Self-Communication is God in Godself, without any remainder..$^{53}$

While we do not have any objection with the first clause of Rahner's Grundaxiom, the second clause that exhausts 'immanent Trinity' in the 'economic' manifestations, needs to be contested. Yves Congar also questioned the second clause-- the 'economic' Trinity is the 'immanent Trinity' arguing that this clause entails a gratuitous identification of 'the free mystery of the economy and the necessary mystery of the Tri-unity of God. ${ }^{54}$ Fred Sanders, commenting on Rahner's second clause of the Grundaxiom, says, 'Taken in its most radical sense, this axiom indicates not merely an epistemological focus on the economy of salvation, but (especially in the direction indicated by the vice versa) a denial that God in himself is triune apart from salvation history. ${ }^{55}$

Lacugna, while also evaluating Rahner's conception, observes that, for Rahner, Incarnation serves as the proof of identity of economic and immanent Trinity. ${ }^{56}$ Rahner argues that the Incarnation must be a 'dogmatically certain instance' of the identity between God's being in the economy and God's being as such. ${ }^{57}$ Hence it implies that the 'particularities of the economy' must reveal that which is unique about the person of the Logos. ${ }^{58}$ He conceives of absolute certainty of divine self-communication in the event of the Incarnation of Logos, and anything less than totality is not acceptable.

\footnotetext{
${ }^{51}$ Rahner and Donceel, The Trinity, 40.

${ }^{52}$ Lincicum, 'Economy and Immanence: Karl Rahner's Doctrine of the Trinity,' 114.

${ }^{53}$ Karl Rahner, 'Trinity, Divine,' Sacramentum Mundi: An Encyclopedia of Theology (vol. 6; New York: Herder \& Herder, 1970), 298.

${ }^{54}$ Yves Congar, I Believe in the Holy Spirit, trans. David Smith, vol. 3 (New York: Seabury, 1983), 13.

${ }^{55}$ Fred Sanders, 'The Trinity,' J. B Webster, Kathryn Tanner, and Iain R Torrance, The Oxford Handbook of Systematic Theology (Oxford; New York: Oxford University Press, 2007), 40.

${ }^{56}$ LaCugna, God for Us, 212.

${ }^{57}$ Ibid. citing Rahner and Donceel, The Trinity, 27

${ }^{58}$ Ibid.
} 
While agreeing with the basic premise of Rahner's axiom-comprising of both the clauses--and its contribution toward revitalizing the doctrine of the Trinity, Lacugna suggests that it needs proper interpretation and corresponding application. She raises a series of pertinent questions:

Is it literally true that the economic Trinity is the Immanent Trinity as the tautology $A=A$ ? Is God with us exactly identical to God as such? Is, therefore, in other words, a strict ontological identity between the eternal and temporal aspects of the one divine self-communication? If so, it would be difficult to see how Rahner's axiom differs from pantheism (Hegelianism or otherwise), the view that God is nothing other than the world or world-process. ${ }^{59}$

She is quick to add that Rahner did not intend his Grundaxiom to imply Hegelianism or any form of a pantheistic notion. She grapples with these questions on the epistemological level, for she fears that any introduction of ontological division between theologia and oikonomia will irreconcilably divide them. ${ }^{60}$ But if the distinction is epistemological, she argues that, then, oikonomia is our means of access to theologia, and it is truly theologia that is given in oikonomia. Despite claiming the ontological similarity between oikonomia and theologia and locating the distinction at the epistemological level, she is wondering 'Whether we can affirm that God as God is totally present in the economy of salvation history, and also maintain that God exceeds and outstrips the human ability to receive or explicate this self-communication?'61

LaCugna conceives 'oikonomia (salvation history) and theologia (God-in-Self)' as two aspects of the one self-communication of God. She says, 'God comes to us through Jesus Christ in the power and presence of the Holy Spirit, which suggests that God exists in differentiated personhood ${ }^{62}$ Following Rahner's lead, she is also critical of Augustine's theology as he relocates the economy within the human soul, removing it away from the events of salvation history. ${ }^{63}$ She notes that Augustine's preoccupation with a procession over the mission, and also starting from the unity of divine essence rather than the plurality of divine persons within the economy has led to the division between theologia (immanent Trinity) and oikonomia (economic Trinity) ${ }^{64}$ She contends that in order

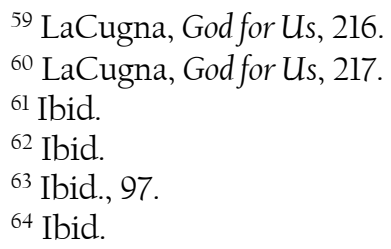


to connect the ad intra relations to the 'missions' in the economy, Augustine had to use the 'appropriation' that assigns one or other activity to the divine persons. Creation is appropriated to the Father, redemption to the Son, and sanctification to the Holy Spirit. However, LaCugna criticizes the doctrine of appropriations as the attributions are often arbitrary and also at times contradict the biblical portrayal of God's activity. ${ }^{65}$

Torrance also disproves the attribution as being superfluous since God is Triune, all his acts toward us cannot but be acts of the Trinity in Unity and of the Unity in Trinity, while in all these acts each Person who is himself whole God acts without any surrender of his distinctive hypostatic properties as Father, Son or Holy Spirit. ${ }^{66}$ Through her critique of Augustine, LaCugna lays out the 'relational ontology' appraisal of the doctrine of the Trinity as she attempts to balance the distinction and correspondence between oikonomia and theologia. Her pursuit for not letting the economic Trinity to subsume immanent Trinity is primarily motivated by her interpretation of the Greek Fathers. She applies the patristic principle, 'the Works of the Trinity ad extra are One' (opera trinitatis ad extra indivisa sunt), and states,

God's activity (operation, energies) in creation originates with the Father, passes through the Son, and is perfected in the Spirit. Thus, the Father creates, redeems, and divinizes through the Son in the power of the Holy Spirit. The Greek formulation displays the biblical and creedal sense of God, the Father who comes to us in Christ and the Spirit. ${ }^{67}$

While maintaining the unity of divine activity in the ad extra, LaCugna is emphasizing the importance of a proper Christological and Pneumatological underpinning for a comprehensive trinitarian perspective. ${ }^{68}$ Her insistence on the intersection of Christology and Pneumatology as proper for a comprehensive understanding is primarily motivated by her doxological turn. Finally, LaCugna identifies the correlation and distinction between the self-communication of God in salvation history and God-in-Self as a 'conceptual' category. ${ }^{69}$ She denies that the distinction is ontological as God is One, and God's SelfCommunication is one that has both eternal and temporal modalities. ${ }^{70}$

${ }^{65}$ LaCugna, God for Us, 98.

${ }^{66}$ Thomas F. Torrance, The Christian Doctrine of God: One Being Three Persons

(Edinburgh: T \& T Clark, 2001), 200.

${ }^{67}$ LaCugna, God for Us, 96.

${ }^{68}$ Ibid., 363.

${ }^{69}$ LaCugna, God for Us, 231.

${ }^{70}$ Ibid. 
The conceptual distinction between economic and immanent Trinity, (or between essence and energies) allows her to conceive God as totally free in bestowing God's very self in God's Self-Communication with human beings, yet to remain ineffable because the human beings are not capable of receiving or understanding the Revealed God in entirety. ${ }^{71}$ This is a nuanced understanding of Rahner's Grundaxiom as LaCugna attempts to maintain the essence of Rahner's conception while avoiding the ontological identity of the immanent Trinity with economic Trinity by positing a conceptual (epistemological) distinction. Thus, she avoids the temptation to misread Rahner's Grunaxiom as a thoroughly pantheistic rendering. However, in the process, she does claim that the immanent Trinity is neither 'transhistorical, trans empirical, or trans economic' nor is the immanent Trinity a 'more real' God. ${ }^{72}$ Her usage of conceptual distinction, however well-conceived it is, becomes a weak defense against maintaining a 'real' distinction between oikonomia and theologia.

Fred Sanders evaluates LaCugna's framework for the doctrine of the Trinity, and observes that it entails 'both a salutary affirmation and an unfortunately polemical denial. ${ }^{73}$ Citing LaCugna, as she categorically states, "the fundamental issue in trinitarian theology is not the inner workings of the 'immanent' Trinity, but the question of how the Trinitarian pattern of salvation history is to be correlated with the eternal being of God."74 Sanders contends, "Such reductionistically economic trinitarianism is equivalent to a denial of the immanent Trinity altogether, and leaves theology with nothing beyond structure, pattern, and history, with no way of referring to the God who takes his stand in that history." ${ }^{75}$ Indeed, the doctrine of the Trinity should not be offered as a set of propositions about the inner life of God without consistently referencing God's self-revelation and self-giving in salvation history. That is, to recount the events of salvation history without letting the "claims of the narrative to push back into the eternal being of God, is to stall out at the level of the economy of salvation without actually saying anything about God himself. ${ }^{76}$

Thomas F. Torrance, on the other hand, is unequivocal when he argues that 'the historical manifestations of God as Father, Son, and Holy Spirit (oikonomia) have evangelical and theological significance only as

\footnotetext{
${ }^{71}$ LaCugna, God for Us, 231.

72 LaCugna, God for Us, 229.

${ }^{73 \prime}$ Fred Sanders, 'Trinity,' Webster, Tanner, and Torrance, The Oxford Handbook of

${ }^{74}$ LaCugna, God for Us, 6.

${ }^{75}$ Fred Sanders, 'Trinity,' Webster, Tanner, and Torrance, The Oxford Handbook of

${ }^{76}$ Ibid., 42.
} Systematic Theology, 41. Systematic Theology, 41. 
they have a transhistorical and transfinite reference beyond their ultimate ground in God himself. ${ }^{77} \mathrm{He}$ further posits that the historical manifestations of the Triune God,

... cannot be Gospel if their reference breaks off at the finite boundaries of this world of space and time, for as such, they would be empty of divine validity and saving significance-they would leave us trapped in some kind of historical positivism. The historical manifestations of the Trinity are Gospel, however, if they are grounded beyond history in the eternal personal distinctions between the Father, the Son, and the Holy Spirit inherent in the Godhead, that is if the Fatherhood of the Father, the Sonship of the Son, and the Communion of the Spirit belong to the inner life of God and constitute his very Being. ${ }^{78}$

Torrance, like Rahner, also considers the incarnation as a key event within the Life of the Holy Trinity but qualifies his statement. For him, the event of Incarnation along with the atonement signifies the 'mutual interpenetration of the Father, the Son, and the Holy Spirit as obtaining in the oikonomia as well as in the theologia, and in the theologia as well as in the oikonomia. ${ }^{79}$ However, he adds, "Although the grace manifested in the economy appeared in history with the incarnate advent of Christ, it derives from and is to be traced back to the eternal outgoing love of God that antedates the creation." ${ }^{80}$ Here Torrance is inferring a dynamic twoway communion between God-in-Self and God's Self-Revelation and by maintaining the priority of theologia over oikonomia, avoids the tendency to subsume latter by the former. Theologia is the transcendental ground for the incarnate oikonomia and without which it will be of 'transient or merely ephemeral significance and therefore without saving power. ${ }^{81} \mathrm{He}$ avers that the theologia and oikonomia are inseparably united in Christ, the eternal Son incarnate among us, for in Christ 'they are anchored in the one Being of the Holy Trinity'. ${ }^{82}$

It is when we consider this movement from God toward man and from man toward God in Christ, together with the movement of the Holy Spirit in his mission from the Father through the Son and in his advocacy of us before the Father, that we may discern how intimately and completely the Father, the Son, and the Spirit are coordinated both in the economic

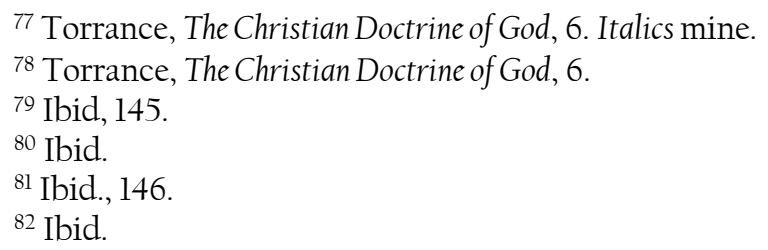


fulfillment of God's revealing and saving acts on our behalf, and in their inner union and Communion with one another. ${ }^{83}$

Torrance, also like LaCugna, emphasizes the intersection of Christology with Pneumatology for a proper doctrine of the Trinity. Without prioritizing one over the other, he states that while the Son of God, and not the Holy Spirit, became incarnate as the selfcommunication of God to us, He, therefore, becomes our direct focus of knowledge of the Holy Trinity. Nevertheless, we cannot recognize Jesus as Lord without the Spirit. While he is not in agreement with the conception that oikonomia is the ground of the manifestation of theologia, he says that not everything that took place in the historical economy can be read back into eternity. ${ }^{84}$ He summarizes this, saying:

... the pattern of coactivity between the Father, the Son, and the Holy Spirit in the economic Trinity is through the Communion of the Spirit a real reflection of the pattern of the coactivity of the Father, the Son, and the Holy Spirit in the ontological Trinity. It is indeed more than a reflection of it, for it is grounded in it, is altogether inseparable from it, and actually flows from it, the intrinsic oneness between the coactivity of the Father, Son and Holy Spirit in the economic Trinity and their coactivity in the ontological Trinity are soteriologically and epistemologically absolutely essential. ${ }^{85}$

This ad extra unity of Godhead, rooted in immanent relations, forms the soteriological and epistemological basis of our grasp of this divine mystery. These immanent and economic aspects of Triunity need further exploration, and perhaps by constructing a model to explicate this, we can shed more light on it.

What is needed is a viable distinction-correlation model that enables the dynamic movement by which oikonomia is sustained by theologia. Use of an interreligious theological application--the 'Qualified Non-Dualism' of the Viśiștādvaita tradition within the Hindu Vedānta schools-- will be proposed as an aid to understanding the oikonomiatheologia relations.

\section{An Interreligious Exploration}

Śankara (650-800 CE) is generally considered as the Founder of the system of Advaita (non-dualism), which is an extended commentary and interpretation of the Upanișad. Moreover, because they are

${ }^{83}$ Torrance, The Christian Doctrine of God, 146.

${ }^{84}$ Torrance, The Christian Doctrine of God, 198.

${ }^{85}$ Ibid., 198. 
considered to constitute 'the 'end' or 'final' portion of the sacred Vedā corpus, the Upanișad is called Vedānta. According to this school of nondualism, the Brahman is nirguna (Attribute-less), and Brahman alone is Absolute Real, and everything else is an illusion (Māya $){ }^{86}$ There is only the apophatic (neti neti, (not this, not that)) description of Brahman, and all qualities that we attribute to Brahman (saguna) are mere projections of our own understanding. This monistic interpretation effectively dissolves the distinction between God and creation. ${ }^{87}$ Rāmānuja (10171137), who is the Founder of the alternative school, Visistitädvaita, developed his philosophical theology as 'Qualified Non-Duality' and the Śrivaisnava community to which he belonged to was devoted to the worship of Viṣnu and his consort Śrī (and therefore called Śrìvaiṣnava). Rāmānuja differs radically in his reading of Vedāntic principles. For him, an absolute understanding of the supreme brahman (parabrahman) always concerns God, in the self-revealed personhood of Nārāayana with his consort Śrī.

For Rāmānuja, while the ineffable aspects of the Brahman of the Vedānta indicate the limits of our understanding of God, 'God has also made available an infinite number of ways of understanding and approaching him-and-her, through our understanding of being but also through our devotion to what is not merely being. ${ }^{88}$ He further states, 'The self is not a singular abstraction of reflexive consciousness but one of an infinite plurality of entities that partake of God by being portions of the divine being. ${ }^{89}$ Rāmānuja posits that this non-duality is viśiștā (qualified) by difference. ${ }^{90}$ His doctrine can be called as 'dentity-indifference. ${ }^{91}$ The human selves are not symmetrically identical with God, for God is infinite, distinctive other than 'self'. God takes selves and world to be the body of the divine self, at once becoming available through our reality and absolutely transcending it.

Rāmānuja propounds an organic conception of the universe using the analogy of 'body and soul': the 'body' modifies the 'soul,' but has no

${ }^{86}$ Chakravarthi Ram-Prasad, Divine Self, Human Self: The Philosophy of Being in Two Gita Commentaries, 1 edition. (Bloomsbury Academic, 2013), xvi. Chakravarthi RamPrasad, Divine Self, Human Self: The Philosophy of Being in Two Gita Commentaries, l edition (Bloomsbury Academic, 2013), xvi.

${ }^{87}$ Ibid., xix.

${ }^{88}$ Ram-Prasad, Divine Self, Human Self: The Philosophy of Being in Two Gita Commentaries, $\mathrm{xx}$.

${ }^{89} \mathrm{Ibid}$.

${ }^{90}$ Monima Chadda, "Hindu Models of Divinity," Graham Oppy, The Routledge Handbook of Contemporary Philosophy of Religion (Routledge, 2015) p. 136.

${ }^{91}$ Ibid. 
separate existence from it, and it is different from the 'soul ${ }^{92}$ Using this analogy, he states, "Similarly, the world constitutes God's body, modifying him, yet have no separate existence from him." 93 The 'world' here as God's body needs to be understood as the aggregate of conscious and non-conscious beings. ${ }^{94}$ The 'ensouled-body' (Brahman-atman) relation in this context is asymmetrical, wherein the encounter is in the dominant position. ${ }^{95}$ Ramanuja asserts that the analogy at the microcosmic level (human body-soul) is also discernable at the macrocosmic (God-World) level. ${ }^{96}$

This 'identity-difference' conception using the 'body-soul' analogy is compelling as an aid to understanding the oikonomia-theologia relations. Here, the phrase 'body modifies the soul' should be construed as not signifying any modification in the 'being' of the soul (in an ontological sense) but serves as a temporal identity for the soul. Rāmānuja modifies the monistic (Advaita) tradition through the use of 'qualified difference' and avoids the collapse of one into another. In this qualified (Viśist distinction by the difference of God-in-Self from God's Self-Revelation, the ensouled is in relation to the body; however, the ensouler is distinct and is in the dominant position. This soul-body analogy will serve as an apt representation of God's Trinitarian-Self in ad extra manifestations in the history of salvation. The body is dependent on the soul for its existence, and the body materially contains ('without containing') the soul. This relationship is identical to the recognition of God's being through acts in oikonomia, but this recognition never exhausts what God is in Godself.

\section{Normative Relationality}

Having understood the oikonomia-theologia relations using Rāmānuja's soul-body analogy as representing the proper relationship of economic and immanent Trinity, let us now return to Torrance's caveat, "Not everything that took place in the historical economy can be read back into eternity." According to this, it can be inferred that there is something that we can read back from the history of salvation into Godin-Godself. However, this has to be done in a qualified-sense in the light of its distinction/difference from eternity as implied in the soul-body

92 Ibid. Also, see A. J Appasamy, The Theology of Hindu Bhakti, (Madras: Published for the Senate of Serampore College, by the Christian Literature Society, 1970). Italics mine.

${ }^{93}$ Ibid.

94 Ibid.

95 Ibid., 137.

96 Oppy, The Routledge Handbook of Contemporary Philosophy of Religion. 
analogy. One such aspect is the imposition of subordinationistic understanding into the Divine Persons' relations within the Trinity. By posting the distinction by relations within the Trinity, Augustine states:

But in God ... everything that is said, ... is said in relation to something, as the Father in relation to the Son and the Son in relation to the Father, which is no accident; because both the one is always Father, and the other is always Son: yet not always, meaning from the time when the Son was born [natus], so that the Father ceases not to be the Father because the Son never ceases to be the Son, but because the Son was always born, and never began to be the Son. ... because each of them is not so-called in relation to Himself, but the terms are used reciprocally and in relation each to the other; ... because they are so-called, not according to substance, but according to relation, which relation, however, is not an accident, because it is not changeable. ${ }^{97}$

While Augustine is trying to explicate the distinction between the three divine Persons through the relations in order to avoid substanceaccident binary, he inadvertently absolutizes the relations. The analogical reference of Father-Son becomes an absolute relation by identifying them in eternity. As the relations of the Father to the Son and of the Son to the Father are fixed in eternity, the associated meanings-human cultural perceptions--also carry over into those terms, signifying a hierarchical relation modeled on human society. And this is also the same with the Spirit of God, being sent by the Father and the Son, indicating a 'secondary' role of the Spirit within the Trinity. Also, the language of Unbegotten, Begotten, Procession, and Spiration also induce an 'order' or hierarchy in the Trinitarian relations. As Gregory of Nazianzus grapples with the terms Unoriginate, Unbegotten, and Precession of Father, Son, and Holy Spirit, he muses:

When did these [Father, Son, and Holy Spirit] come into being? ... And when did the Father come into being? There never was a time when He was not. And the same thing is true of the Son and the Holy Ghost. Ask me again, and again I will answer you. When was the Son begotten? When the Father was not begotten. And when did the Holy Ghost proceed? When the Son was, not proceeding but, begotten- beyond the sphere of time, and above the grasp of reason; ... Because They are from Him, though not after Him. For that which is unoriginate is eternal, but that which is eternal is not necessarily unoriginate, so long as it may be referred to the Father as its origin. Therefore, in respect of Cause, they are not

${ }^{97}$ Augustine, On the Trinity, Book V Chapter 5, http://www.newadvent.org/fathers/130105.htm. 
unoriginate; but it is evident that the Cause is not necessarily prior to its effects, for the sun is not prior to its light. ${ }^{98}$

Gregory identifies the Son and the Spirit in a causal connection with the Father, as Father is the 'Source.' However, he wants to place these causal events beyond time and reason because, in relation to time, Son and Spirit cannot be said to be originating. Gregory also denies the chronological connection between Cause and Effects by using the analogy of sun and light. In the modern understanding of the universe, where there are billions of suns in each galaxy, this might sound trivial. But, given the benefit of the doubt owing to his time (possibly deriving from the Creation account in Genesis), Gregory is tackling an impossible task here. By using the terms like 'origin,' 'begotten,' and 'proceed' that logically signify a chronological sense, it will never be possible to deny the dimension of time.

Moreover, the expressions 'begotten' and 'Spiration' denote a temporal sense-- as past occurrences--that creates difficulty in defining the 'antecedently' and eternally subsisting relations within the Trinity as Father, Son, and Spirit. As Procession and Spiration belong to the ontological/theologia realm, it is only fit to conceive these relations as 'infinite' and eternal. Also, the phrase 'relations of origin' is a no-go as we are forced to talk in terms of the beginning of something in relation to time. Jenson makes an interesting observation, 'Nobody claimed to know exactly what 'begotten' meant ... and yet a tremendous assertion is made: there is a way of being begun, of receiving one's being, which is proper to Godhead itself'. ${ }^{99}$ Being 'begun' and 'receiving' do not correspond with the 'antecedently prior' (Barthian) relations in Godhead. But, Augustine shares passionately about the inner-Trinity egalitarian relations: 'So great is the equality in this Trinity that not only is the Father not greater than the Son in that which pertains to the divinity, but neither is the Father and the Son anything greater than the Holy Spirit nor is each person simply anything less than the Trinity itself. 100

Along with Augustine, one would want to affirm the equality of all three Persons in the Trinity, without reading from the salvation history back into the Trinity, imposing humanly conceived hierarchy or subordinationism. To accomplish that task, we need to move away from the temporally defined terms such as 'begotten' or 'proceed' to the defining relationship of perfect mutuality within the Trinity using

\footnotetext{
${ }^{98}$ Gregory of Nazianzus, Orations: 'Third Theological Oration' (Oration 29), http://www.newadvent.org/fathers/ 310229.htm.

${ }^{99}$ Jenson, The Triune Identity, 85.

${ }^{100}$ Augustine, On the Trinity, Book VIII Pref., http://www.newadvent.org/fathers/ 130108.htm.
} 
perichoresis. Colin Gunton defines the concept of perichoresis as the 'reciprocal eternal relatedness.' ${ }^{101}$ He adds, "God is not God apart from the way in which Father, Son, and Spirit in eternity give to and receive from each other what they essentially are. The three do not merely coinhere, but dynamically constitute one another's being." 102 Jürgen Moltmann describes perichoresis as '[ $t$ ] he 'circulation' of the eternal divine life becomes perfect through the fellowship and unity of the three different Persons in eternal love. ${ }^{103}$ The soul-body analogy of Viśisțādvaita helps to reconceive the relation of the oikonomia-theologia Trinity, and perichoresis represents the co-equal relationship within the God-head.

\section{Conclusion}

To recap our sequence of the exploration of the doctrine of the Trinity: we started with the early Christian believers' 'historical recognition' (recognition in the salvation history) of the triune identity of God. This was possible as they reconstituted the current understanding of Jewish monotheism through the intersection of Christology and Pneumatology. Though it depended on the existing Jewish tradition about divine agency, angelology, and exaltation of patriarchs, it turned out to be a radically new phenomenon as Jesus was conceived in his identity with One God. The conception of the Spirit of God as a Person and executor of God's mission initiated through the Son of God. Thus, a relational paradigm within the trinitarian revelation was unveiled. Following this relational understanding, we evaluated the 'substance' ontology as was prevalent in the Christian theologizing enterprise, especially the Western tradition for many centuries, and replaced it with the 'relational' understanding of God. This relational understanding avoided the 'substance speculation' of ineffable God's essence and focused on God as a relational being.

Thus, we turned our focus on oikonomia, the domain of God's salvific action, as the task of theologizing is made possible through our study of God's activities in the human realm. However, as oikonomia is bound up with theologia, (God-in-Self), we sought to evaluate Rahner's Grundaxiom for the merit of its two clauses. While the first clause-'Economic Trinity is immanent Trinity'--was non-contentious, the second clause--'Immanent Trinity is Economic Trinity'--does raise issues, as God's transcendence is sought to be subsumed within the

${ }^{101}$ Gunton, The Promise of Trinitarian Theology, 164

102 Gunton, The Promise of Trinitarian Theology, 164.

103 Jürgen Moltmann, The Trinity and the Kingdom: The Doctrine of God (London: SCM Press, 2005). 
human domain. LaCugna's defense of Rahner's Grundaxiom through the 'conceptual' (epistemological) distinction to avoid 'ontological' division turns out as a weak defense. Though doxological and soteriological perspectives are worthy aspects in themselves, as Torrance points out, unless oikonomia is grounded in theologia, it will lose its efficacy. The soulbody analogy of Viśiștādvaita presents a relevant model to construe a properly sustaining, and dynamic model. The theologia (soul) is understood to sustain oikonomia (body) and oikonomia to 'reveal' (as a finite body) theologia. This use of Visitadvaitic body-soul analogy provides a viable model to visualize the oikonomia-theologia relation in a 'qualified panentheistic' manner that maintains the distinction without succumbing to the temptation of subsuming one with the other or of just conceiving a 'conceptual' difference.

Also, by moving away from the temporally defined terms such as 'origin,' 'begotten,' 'generated' etc., and conceiving the intra-Trinitarian relations in purely relational terms--the interpenetrating, identityconstituting, perfect reciprocity of three Divine Persons--we can construe the perfection of equality within the Trinity. However stronglyattested the norm of naming God as Father, Son, and Spirit in the Scriptural and historical traditions may be, the anthropomorphically constituted cultural meanings that are associated with these types of nomenclatures can be neutralized only when theologizing tasks assign precedence to the perichoretic relationships within the Trinity. In this quest, this theological exploration sheds some positive light.

\section{Bibliography}

Appasamy, A. J. The Theology of Hindu Bhakti. Madras: Published for the Senate of Serampore College, by the Christian Literature Society, 1970.

Astika, Made. "Doctrine of Trinity: A Theological Approach of Evidence of The Trinity in The New Testament." Jurnal Jaffray 10, no. 2 (October 1, 2012): 1-15. https://doi.org/10.25278/jj7l.vl0i2.50.

Fee, Gordon D. Jesus the Lord According to Paul the Apostle: A Concise Introduction. Grand Rapids: Baker Academic, 2018.

Gunton, Colin E. The Promise of Trinitarian Theology. Edinburgh: T \& T Clark, 1991.

Hasker, William. Metaphysics and the Tri-Personal God, 2013.

Helmer, Christine. "Luther's Trinitarian Hermeneutic and the Old Testament." Modern Theology 18, no. 1 (2002): 49-73. https://doi.org/10.1111/14680025.00176 .

Hurtado, Larry W. One God, One Lord: Early Christian Devotion and Ancient Jewish Monotheism. Philadelphia: Fortress Press, 1988. 
Jenson, Robert W. The Triune Identity: God According to the Gospel. Philadelphia: Fortress Press, 1982.

Kärkkäinen, Veli-Matti. Trinity and Revelation, 2014.

LaCugna, Catherine Mowry. God for Us: The Trinity and Christian Life. [San Francisco]: HarperSanFrancisco, 1991.

Lincicum, David. "Economy and Immanence: Karl Rahner's Doctrine of the Trinity." European JOurnal of Theology 14, no. 2 (2005): 111-18.

McCall, Thomas H. Which Trinity? Whose Monotheism?: Philosophical and Systematic Theologians on the Metaphysics of Trinitarian Theology. Grand Rapids, Mich.: W.B. Eerdmans Pub. Co., 2010.

Moltmann, Jürgen. The Trinity and the Kingdom: The Doctrine of God. San Francisco: Harper \& Row, 1981.

Oppy, Graham. The Routledge Handbook of Contemporary Philosophy of Religion. Routledge, 2015.

Rahner, Karl, and J. F Donceel. The Trinity. London; New York: Burns \& Oates, 2001. http://public.eblib.com/choice/publicfullrecord.aspx?p=436043.

Ram-Prasad, Chakravarthi. Divine Self, Human Self: The Philosophy of Being in Two Gita Commentaries. 1 edition. Bloomsbury Academic, 2013.

Rowe, C. Kavin. "Biblical Pressure and Trinitarian Hermeneutics." Pro Ecclesia: A Journal of Catholic and Evangelical Theology 11, no. 3 (2002): 295-312. https://doi.org/10.1177/106385120201100303.

Shults, F. LeRon. Reforming the Doctrine of God. Grand Rapids, Mich.: W.B. Eerdmans Pub. Co., 2005.

Torrance, Thomas F. The Christian Doctrine of God: One Being Three Persons. Edinburgh: T \& T Clark, 1996.

Webster, J. B, Kathryn Tanner, and Iain R Torrance. The Oxford Handbook of Systematic Theology. Oxford; New York: Oxford University Press, 2007.

Zizioulas, Jean. Being as Communion: Studies in Personhood and the Church. Crestwood, N.Y.: St. Vladimir's Seminary Press, 1993. 